\title{
КОМПЛЕКСЫ ВИСМУТА С 15- И 18-ЧЛЕННЫМИ АЗАКРАУН АЦЕТАТАМИ КАК КОМПОНЕНТЫ РАДИОФАРМПРЕПАРАТОВ
}

\author{
Б.В. Егорова', Е.В. Матазова', А.Д. Зубенко², Г.Ю. Алешин', \\ А.В. Пашанова ${ }^{2}$, А.Л. Тригуб³, О.А. Федорова², С.Н. Калмыков ${ }^{1}$ \\ ${ }^{1}$ Химический факультет, МГУ имени М.В. Ломоносова, \\ 119991, РФ, Москва, Ленинские горы, $1 / 3$. \\ ${ }^{2}$ ИНЭОС РАН им. А.Н. Несмеянова, 119991, РФ, Москва, ГСП-1, ул. Вавилова, 28. \\ ${ }^{3}$ НИЦ «Курчатовский институт», 123182, РФ, Москва, пл. Академика Курчатова, 1.
}

DOI: 10.19163/MedChemRussia2021-2021-124_E-mail: bayirta.egorova@gmail.com

Одними из перспективных для терапии новообразований являются радионуклиды, испускающие альфа-частицы, ${ }^{212,213} \mathrm{Bi}$. Для связывания катионов радионуклидов, в т.ч. $\mathrm{Bi}^{3+}$ в качестве компонентов радиофармпрепаратов используются и исследуются ацетатные производные азакраун соединений (в первую очередь, $\mathrm{H}_{4}$ DOTA - 12-членный макроцикл). Комплексы краун-эфиров вследствие макроциклического эффекта характеризуются высокой устойчивостью в условиях живого организма по сравнению с хелатами ациклических полиаминов. Однако последние образуют комплексы при комнатной температуре за короткое время, что важно для короткоживущих изотопов висмута. В рамках нашей работы мы совместили свойства ациклических и макроциклических лигандов за счёт увеличения макроциклической полости. Было изучено комплексообразование три- и тетраацетатных 18-азакраун-6 и 15-азакраун-5 с катионами висмута. Определены константы комплексообразования, получены меченные изотопом ${ }^{207} \mathrm{Bi}$ комплексы. Рассмотрена их устойчивость в средах биологического значения, в т.ч. in vivo.

Показано, что значение $\lg \mathrm{K}(\mathrm{BiL})=21$ достаточно для образования устойчивого к гидролизу комплекса. При этом, на устойчивость комплексов в живых системах наибольшее влияние оказывает структура лиганда. Тетраацетат 18-азакраун-6 (Н ВАTA) представляет собой раскрытую модификацию лиганда $\mathrm{H}_{4}$ DOTA и образует комплексы схожей инертности, в присутствии катионов микроэлементов и сывороточных белков. Однако, ввиду большего размера макроцикла диссоциация в кислой среде (pH1) происходит значительно быстрее, чем в случае, $\mathrm{H}_{4}$ DOTA. С другой стороны, в данном случае быстрая диссоциация в кислой среде говорит о высокой подвижности протонов у аминогрупп, что и приводит к высокой скорости образования комплекса. Кроме того, лиганд триацетат 18-азакраун-6 образует комплексы с $\mathrm{Bi}^{3+}$ с меньшим значением $\operatorname{lgK}$, чем триацетат 15-азакраун-5, но демонстрирует меньшее накопление в органах in vivo, что подтверждает эффективное экранирование катиона $\mathrm{Bi}^{3+}$ в составе комплексов с производными 18-азакраун-6.

Работа выполнена при финансовой поддержке РНФ грант №18-73-10035

$$
-124-
$$

